\title{
Scottish Paediatric Society and British Paediatric Association
}

\author{
Proceedings of a Joint Meeting
}

A joint meeting between the Scottish Paediatric Society and the British Paediatric Association was held at Aviemore from 20 to 24 April 1982. 321 members and 10 associate members attended, together with 3 Heinz Fellows and 216 guests. The Windermere Lecture was given by Professor Mary Ellen Avery, Thomas Morgan Rotch professor of paediatrics(Harvard Medical School, Boston, Massachusetts) and the Scottish Paediatric Society Fifth Jubilee Lecture was given by Professor E M McGirr (Chairman, Scottish Council for Postgraduate Medical Education).

A plenary session on Paediatric Urology was mounted by the British Association of Paediatric Surgeons on 23 April.

The Annual General Meeting of the British Paediatric Association was held on Thursday 22 April 1982. The President, Dr G M Komrower, was in the chair. The minutes of the last meeting, which had been published in the Archives of Disease in Childhood, were received and approved.

ELECTION OF OFFICERS: The following will serve the Association for 1982-83.

PRESIDENT:

HONORARY TREASURER:

HONORARY SECRETARY:

HONORARY ASSISTANT SECRETARIES:

\section{Prof Sir Peter Tizard Dr A D M Jackson Dr D R Harvey}

Dr J D Baum

Dr T L Chambers

Dr D W Fielding
NEW MEMBERS OF COUNCIL: Dr E McKay, Dr J Martin, Dr R E Olver, Dr E Mac D Ross, Dr A L Speirs, Dr R G Welch, Dr B A Wharton.

HONORARY MEMBERS: Dr S J Carne, Dr J O Craig, Professor J L Emery, Dr R A Shanks.

MEMBERS: L N J Archer (Leicester), R C Beach (Southampton), T J Beattie (Manchester), Sarah J Bodden (Derby), Margit Bommen (London), A W Boon (Sheffield), Margaret Borzyskowski (London), Elizabeth A E Brown (London), Sarah Bundy
(Birmingham), C A Campbell (London), N D Carter (London), K C Chin (Birmingham), S Chong (London), G C Close (Manchester), Gaynor F Cole (London), C Costalos (Greece), Kathleen L Costeloe (Slough), Marion Crouchman (London), R E Cudmore (Liverpool), Jean S Davies (Southampton), H Dellagrammaticas (Greece), N R Dennis (Southampton), B Donaldson (Glasgow), Margaret Drummond (Glasgow), Gillian C L Du Mont (London), N V Freeman (Southampton), W J Fysh (London), Margaret Gallagher (Dublin), Ann Gath (Bury St Edmunds), Jean Golding (Oxford), M A Hall (Southampton), Susanna M Hart (London), D P Heaf (London), J A Hulse (London), R Hume (Edinburgh), Mary Johnson (Manchester), P M Jones (Newcastle), Rosamond A K Jones (Norwich), C J H Kelnar (London), Patricia A Kenny (London), Alison M Kerr (Glasgow), S D Levin (London), A Lucas (Cambridge), J McKiernan (Cork), A McNinch (Exeter), N P Mann (Nottingham), J A M Martin (London), P E Minchom (Cardiff), J Mitchell (London), J F Murphy (Cardiff), A R Nicol (Newcastle), D Ogilvie (Carshalton), Kathleen Pearl (London), C A Pennock (Bristol), B M Reynolds (Glasgow), R J Richardson (Brunei), C P Q Sainsbury (Cardiff), Ruby H Schwartz (Harrow), D J Scott (Germany), J F Smallhorn (London), S E W Smith (Leeds), L Spitz (London), G Supramaniam (London), M C G Stevens (Oxford), D N K Symon (Aberdeen), G P Taylor (London), S J Tuck (Norwich), $\mathbf{S}$ Variend (Sheffield), Giorgina $\mathbf{M}$ Vergani (London), M Watkinson (London), Helen M M Wesley (East Berks), S Wolkind (London).

ASSOCIATE MEMBERS: S I G Adamson (Eastern Health and Social Services Board, Northern Ireland), $\mathbf{K}$ Balachandran (Barnsley AHA), Sonia Bolton (Hampshire AHA), Mary Donovan (Mid Western Health Board, Irish Republic), Mary Ellis (Bolton AHA), Rita A Forrest (Tayside Health Board), Elizabeth Grantham (Cambridgeshire AHA), Diana Gordon (Wiltshire AHA), S M Gumpel (Kensington, Chelsea, and Westminster AHA), Cicely Haines (Wiltshire AHA), Lydia Heaton (St Helens and Knowsley AHA), Ann Kilpatrick (Hampshire AHA), 
Anne C Langlands (Tayside Health Board), Nora Lawton (Stockport AHA), Jocelyn H W Newman (Enfield and Haringey AHA), Elizabeth M Robertson (Tayside Health Board), K Singh (Ealing, Hammersmith, and Hounslow AHA), Beryl Stringer (Lancashire AHA).

\section{Report of the Council 1981-82}

\section{OBITUARIES}

The Association has suffered the loss of $\mathrm{Dr}$ Livmedikus E Bottiger (Honorary Member), Dr W H P Cant (Honorary Member), Sir Lorimer Dods (Honorary Member), Professor Sir Douglas Hubble (Honorary Member and first Chairman of the Academic Board), Professor C A Janeway (Honorary Member), Professor B Landtman (Honorary Member), Dr Agnes Macgregor (Honorary Member), Dr R Old (Associate Member), Professor R E Steen (Honorary Member and past President), and Dr K H Tallerman (Honorary Member and past President). The Association is also sad to record the death of Dr J Sakula, who was a member until his resignation after retirement.

\section{MEMBERS DISTINCTIONS DURING 1981-82}

Professor J P M Tizard was knighted; Dr Barbara Ansell received a CBE; Dr Marion Jepson received an MBE; Sir Cyril Clarke received the Artois-Baillet Latour Health Prize for 1981; Professor V Dubowitz has been nominated for the 1982 Arvo Ylppo Award Medal; Professor R S Illingworth has been awarded the Freedom of the City of Sheffield.

\section{COUNCIL}

Membership: The following members of the Association have served on Council during 1981-82: Dr G M Komrower (President), Dr D P Addy, Dr J D Andrew, Dr J D Baum (Honorary Assistant Secretary), Dr O G Brooke, Professor A G M Campbell (Chairman of the Academic Board), Dr T L Chambers (Honorary Assistant Secretary), Professor F Cockburn, Dr D W Fielding (Honorary Assistant Secretary), Dr W R Forbes, Dr L Haas, Dr D R Harvey (Honorary Secretary), Dr A D M Jackson (Honorary Treasurer), Dr R D Jones, Dr B W Lewis, Dr G M Lewis, Professor B McNicholl, Dr M W Moncrieff, Dr C A Potter, Dr M Reid, Dr D C Robinson, Dr L Rosenbloom, Dr K Simpson, Dr J Syme, Professor Sir Peter Tizard (President-Elect), Dr H B Valman, Dr G H Watson, Dr S G F Wilson, Dr R S Trompeter, Dr Anita Jenkins, and Dr Elizabeth Pryce-Jones (Associate Members' representatives).
Observers: The Association is grateful to the following for assistance and advice both at Council and in many other ways: Dr W J Appleyard (Central Committee for Hospital Medical Services), Dr Margaret Bell (Department of Health and Social Services, Northern Ireland), Professor F S W Brimblecombe (Children's Committee), $\mathrm{Mr} \mathrm{A}$ Jolleys (British Association of Paediatric Surgeons), Professor R G Mitchell (Association of Clinical Professors and Heads of Departments of Paediatrics), Professor T E Oppé (Adviser in Child Health, DHSS), Dr Marie Richards (Welsh Office), Mr J E S Scott (British Association of Paediatric Surgeons), Dr B C S Slater (Scottish Home and Health Department), Professor C E Stroud (Standing Medical Advisory Committee), Dr A Yarrow (Department of Health and Social Security).

Meetings. Council met on three occasions-6 June and 24 October 1981, and 20 February 1982.

\section{MATTERS CONCERNING THE ADMINISTRATION OF THE ASSOCIATION}

The Association's staff comprises an Executive Secretary and five Assistant Secretaries; two of the Assistant Secretaries are half-time and were first employed during 1981. The Executive Secretary now works three-quarters time.

The Association would again like to record its debt to the Institute of Child Health for mailing services and the use of rooms for meetings.

Academic Board. The 16th Annual Report of the Academic Board has been received by Council and is published as an Appendix.

Association's Journal. Dr H B Valman was appointed Editor of the Archives of Disease in Childhood to replace Professor R J Robinson from April 1982.

\section{AWARDS OF THE ASSOCIATION}

James Spence Medal: Council was pleased to nominate Dr D MacCarthy to receive this.

\section{Guthrie Medal: Dr A Lucas.}

Heinz Fellowships of the BPA: Heinz Fellowships for 1982-83 have been awarded to Dr A K Chopda (India) and Dr G W Zirembuzi (Uganda)-Fellowship $\mathrm{A}$; and $\mathrm{Dr} \mathrm{A} \mathrm{R}$ Wilkinson-Fellowship C. The Association is indebted to the Nuffield Foundation for its advice and administrative help. The Association has now taken over the administration of the Fellowships from the Nuffield Foundation, 
but the Foundation will continue to be responsible for the financial arrangements and the appointment of Fellows until the BPA receives charitable status; Dr David Yonge has been immensely helpful in advising the Association about the administration of the Fellowships. The Association continues to be grateful to the Heinz Company for funding these valuable Fellowships.

\section{FINANCE AND ALLIED MATTERS}

The Directors of Unigate have again generously donated their annual travel grant $(£ 250)$ and are supplying the programme and stationery for the 1982 Annual Meeting.

A contribution has again been received by the Association from the Trustees of the Moorgate Trust Fund. The Association is extremely grateful for the donation of $£ 600$.

A prize of $£ 100$ was presented to Dr J G Watson for the best paper presented in a plenary session at the 1981 Annual Meeting by a paediatrician below consultant status. This money was given by Commander and Mrs A H Blacow in memory of their son Michael.

The BPA continues to benefit by a share of the profits from the sale of the Archives of Disease in Childhood. Negotiations are in progress with the British Medical Journal for the future administration of the Archives.

\section{MEETINGS OF THE ASSOCIATION}

The 53rd Annual Meeting of the Association was held at York in April 1981. 905 members and guests attended. Council thanks the Academic Board for organising the scientific programme of these meetings and the many members and guests who submitted papers. Council also wishes to thank the conveners and members of specialty groups (13 of which held sessions during the meeting) for their contributions. During the year a new specialty group has been approved by Council-Child Psychiatry and Psychological Medicine.

The next Annual Meeting of the Association will be held in York from 12 to 16 April 1983.

\section{STANDING COMMITTEES AND WORKING PARTIES OF THE ASSOCIATION}

The following working parties and committees were set up during the year: Appeals committee; working party on the future of British paediatrics; working party to provide comments on the British Psychological Society's Report 'Psychological services for children'; working party on primary care in the inner cities; working party on the definition of handicap; joint working party of the British Paediatric Association and the Faculty of Ophthalmologists; working party on women in paediatrics.

Two surveys on manpower were conducted during the year: (a) A survey of the retirement dates of all consultant paediatricians and the numbers of senior registrars and registrars, including honorary posts. (Council is grateful to Dr M Bellman and Dr A P Norman for helping with this study.) (b) A survey of paediatric registrars who were in post in 1977, to find out how their careers had progressed two years later. (Council is grateful to Dr M Liberman for analysing this study.)

\section{MATTERS CONCERNING GOVERNMENT DEPARTMENTS AND OTHER BODIES}

Comments on or to the following have been submitted: Department of Health and Social Security: Administrative arrangements in health districts after 1982; Bone age $x$-ray films on prospective immigrants; Child abuse-central register system. World Health Organisation: Draft international code of marketing of breast milk substitutes. National Institute for Social Work: Evidence was submitted to the working party on the roles and tasks of social workers. Children's committee: The needs of the under-fives in the family. House of Commons: Meeting the cost of visiting children in distant hospitals.

Council is deeply grateful to the members who have served on committees and working parties, and also to those who have represented the Association on both statutory and voluntary bodies. Many individual members have helped the Association by their advice, suggestions, and criticisms.

Council again wishes to record its special appreciation of the work of the editors of the Archives of Disease in Childhood; the journal continues to be of the greatest value to British paediatrics.

APPENDIX

Sixteenth Annual Report of the Academic Board 1981-82.

1. Scientific Meeting. The Annual Meeting of the Association was held at York University from 7 to 11 April 1981. Dr Barbara Ansell gave the George Frederic Still lecture 'Chronic childhood arthritis today'. Plenary sessions on 'Paediatric cardiology' and 'Accidents in childhood' were organised by the British Paediatric Cardiology Section and the BPA/ 
BAPS Joint Standing Committee on Childhood Accidents respectively. A seminar was held on 'Nucleus hospital design' and the first classroom course was presented by Margaret Mearns on 'Personal practice in the care of children with cystic fibrosis'.

Fifteen free papers were presented in plenary sessions. There was also a display of 28 posters in the Central Hall. A further 157 papers were given in group sessions organised by: British Paediatric Cardiology Section jointly with British Paediatric Cardiology Group; British Paediatric Immunology and Infectious Disease Group; British Paediatric Neurology Association; British Paediatric Nutrition, Metabolism, and Pharmacology Group; British Paediatric Tropical Child Health Group; Community Paediatric Group; British Paediatric Perinatal Group; British Paediatric Radiology Group; British Society for Paediatric Endocrinology; British Paediatric Gastroenterology Group; British Association for Paediatric Nephrology; British Paediatric Oncology and Haematology Group; British Paediatric Respiratory Group. In addition films of paediatric interest were shown.

2. Academic Board Meetings. The Academic Board met three times during the year.

3. Research in Paediatrics. The Research subcommittee met twice. The following terms of reference were drawn up: (a) to centralise expertise on grant giving bodies in relation to research in paediatrics and child health; (b) to draw up and keep up to date an index of who is doing what in paediatric research in this country; (c) to develop expertise on dealing with problems in relation to conducting paediatric research-for example, honorary contract units of medical time, work counting towards higher specialist training, ethical problems, terms and conditions of service; (d) to maintain a dossier on the personnel structure of academic departments in this country; (e) to maintain an interest in the problems of full-time scientists in paediatric departments; part-time women doctors in paediatric research; overseas scientists.

Funds were still being sought for a permanent research secretary. In the meantime Dr J A Black, who has recently retired, offered his services as Honorary Research Secretary to the Academic Board. A statement was being prepared on 'Future of paediatric research in the UK'.

4. Future Meetings of the BPA. In 1982 the BPA joins the Scottish Paediatric Society at a meeting in Aviemore to celebrate the Society's diamond jubilee. A plenary session will be organised by the British
Association of Paediatric Surgeons on 'Paediatric urology'. Personal practice sessions will be held on asthma and diabetes, presented by Professor A D Milner and Dr J O Craig respectively.

Members of the British Paediatric Association have been invited to participate in the German Paediatric Congress in September 1982 under the Presidency of Professor Horst Bickel. Twenty-three representatives of the BPA will have their expenses paid by the German Paediatric Society.

The 1983 Annual Meeting will once again be at York where the BPA will be joined by representatives of the Canadian Paediatric Society.

In 1984 representatives of the Belgian Paediatric Society will participate in the BPA Annual Meeting.

5. Membership. The period of office of Professor D Hull as Chairman and that of Professor J W Scopes as member of the Academic Board ended with the Annual General Meeting in 1981. Both members were warmly thanked by the Board for the work they had done for the Association. Professor A G M Campbell has taken up office as Chairman to the Board. Professor D Hull remains as a co-opted member of the Board as he has succeeded Professor C E Stroud as Adviser in Child Health to the DHSS Chief Scientist. In addition Professor A S McNeish and Dr J S Wigglesworth have been elected to the Board.

\section{SCIENTIFIC PROCEEDINGS}

WINDERMERE LECTURE. The lecture was delivered by Professor Mary Ellen Avery, Thomas Morgan Rotch professor of paediatrics, of Harvard Medical School, Boston, Massachusetts, on 'Our patients at highest risk: the new population of very low birthweight infants.'

SCOTTISH PAEDIATRIC SOCIETY FIFTH JUBILEE LECTURE. The lecture was delivered by Professor E M McGirr, Chairman of the Scottish Council for Postgraduate Medical Education, on 'Men are but children of a larger growth'.

\section{The 'gently battered' child. J L Emery (Sheffield).}

Among babies and infants that present as unexpected deaths are a small number who, on full pathological examination by a paediatric pathologist, no naturally adequate cause of death is found and these are often called true cot deaths. In a proportion of these, later confidential information which arises in interviews with parents and others indicates that some of these children have died as a result of some form of suffocation such as pinching the nose. 
These cases, even when confessed to the police, are incapable of being sustained in court due to the wide acceptance of the cot death syndrome.

Our own recent survey of child deaths suggests that the 'gently battered' child is now a more common cause of death in the postperinatal period than are deaths due to classical non-accidental injury.

Two-dimensional echocardiographic visualisation of patent ductus arteriosus in the sick neonate. $J$ F Smallhorn, R H Anderson, F J Macartney (London).

Few doubt that a widely patent ductus arteriosus (PDA) profoundly affects the course and management of neonates, particularly with respiratory distress syndrome. But there is controversy both as to the aetiology of PDA and the optimal treatment (medical or surgical). This results partly from lack of an objective diagnostic method for PDA, and partly also from lack of a means of proving closure. Clinical examination and left atrial/aortic ratio measurement by $\mathbf{M}$-mode echocardiography are only indirect diagnostic methods, and not always accurate. Precordial two-dimensional echocardiography has been tried, but is inaccurate. Direct noninvasive visualisation of the ductus is essential.

We therefore used suprasternal two-dimensional echocardiography with a $5 \mathrm{MHz}$ transducer in 20 neonates with isolated PDA, 5 weighed below $1200 \mathrm{~g}$. By identifying the descending aorta, and tracing the left pulmonary artery from the pulmonary trunk to the left hilum, the PDA was imaged in each case. One patient was given indomethacin. Ductal closure mirroring clinical improvement was observed with two-dimensional echocardiography.

In a control group of 20 neonates without PDA, no false-positive diagnosis was made. Suprasternal two-dimensional echocardiography seems an accurate method of direct visualisation of the ductus, though $5 \mathrm{MHz}$ resolution would probably not demonstrate a lumen less than $2 \mathrm{~mm}$ across.

Screening for tetrahydrobiopterin $\left(\mathrm{BH}_{4}\right)$ deficiency among newborns with phenylketonuria. I Smith, R Leeming, O H Wolff (London and Birmingham).

Phenylketonuria is usually due to impairment of phenylalanine hydroxylase activity; about $1 \%$ of cases are due to deficiency of $\mathrm{BH}_{4}$, the co-factor for hydroxylation of phenylalanine to tryosine, tyrosine to dopa, and trytophan to $50 \mathrm{H}$-tryptophan. There is urgent need for a means of screening new cases of phenylketonuria for $\mathrm{BH}_{4}$ deficiency to ensure that treatment with neurotransmitter precursors can be started before symptoms appear.

Forty consecutive new patients with phenylketo- nuria have been tested by measuring total plasma biopterin activities using Crithidia fasciculata assay. Thirty patients with presumed hydroxylase defects and phenylalanine levels of over $1200 \mu \mathrm{mol} / \mathrm{l} \mathrm{had}$ plasma biopterin levels of between 4.5 and $19.5 \mu \mathrm{g} / 1$ (normal $1 \cdot 78 \pm 0.025$ ); as phenylalanine levels fell biopterin levels also fell. One patient had plasma biopterin levels of $21.6 \mu \mathrm{g} / \mathrm{l}$ and levels remained high even when phenylalanine levels were controlled. This pattern is characteristic of dihydropteridine reductase (DHPR) deficiency. DHPR is the enzyme required for conversion of dihydrobiopterin $\left(\mathrm{BH}_{2}\right)$ to $\mathrm{BH}_{4}$; deficiency causes accumulation of $\mathrm{BH}_{2}$ and its precursors.

$\mathrm{BH}_{4}$ deficiency may also occur because of failure of biosynthesis of $\mathbf{B H}_{2}$. Plasma biopterin activity is then low $(<1 \mu \mathrm{g} / \mathrm{l})$ even when phenylalanine levels are increased. Thus measurement of plasma biopterin activity enables the different variants of phenylketonuria to be distinguished.

Avoidable perinatal factors in childhood handicap: the obstetric and neonatal audit of the future? A Whitelaw, I MacFadyen (Harrow).

Obstetric and neonatal records were scrutinised from 115 of the 122 developmentally handicapped children born in one hospital during 1974-77. These were compared with 82 randomly chosen normal children born in the same hospital during the same four years and living in the same area. Seventeen $(81 \%)$ out of 21 of cerebral palsied children had at least one of the following high risk factors: fetal distress, antepartum haemorrhage, cord prolapse, difficult breech delivery, low Apgar score, failed intubation, hypoxia, or hypoglycaemia. Only $14 \%$ of the cerebral palsied children had respiratory distress and only $9.5 \%$ were ventilated. Mental retardation (without cerebral palsy) and developmental delay were not associated with perinatal asphyxia but rather with dysmorphic syndromes and birthweights below the 5th centile. Language delay was associated with preterm delivery, fetal distress, difficult breech delivery, low Apgar scores at five minutes. Potentially avoidable obstetric or neonatal factors were present in $42 \%$ of cases of cerebral palsy. There is a case for automatic notification of all new cases of cerebral palsy to the place of birth so that clinicians there can review the perinatal events.

Clinical application of an open-loop infusion system in adolescents with insulin-dependent diabetes mellitus. S A Greene, J D Baum (Oxford).

Continuous open-loop infusion systems (CSII) 
have been used successfully in adults who have unstable diabetes, with improvements in diabetic control. Experience with these systems is limited and there are no reports from the UK on their use in children or adolescents.

We report the use of such a system (Autosyringe AS6C model) in 3 teenage diabetic boys, aged 17, 16 , and 13 years. In each case insulin is infused at an individually calculated continuous basal rate with preprandial bolus doses given manually. The infusion is subcutaneous into the abdominal wall via a fine gauge butterfly needle. This system is changed daily.

Before CSII the swings in the 24-hour blood glucose profiles expected on standard injections of short and intermediate acting insulin were demonstrated in each case. With CSII these swings in the 24-hour blood glucose profiles decreased in each case. The mean blood glucose values on standard injection therapy were $9 \cdot 1 \pm 5 \cdot 2,8 \cdot 8 \pm 4 \cdot 2$, and $6 \cdot 4 \pm 3 \cdot 2$ $\mathrm{mmol} / \mathrm{l}$ respectively. After CSII these all fell to $8 \cdot 4 \pm$ $2 \cdot 8,8 \cdot 4 \pm 3 \cdot 5$, and $5 \cdot 9 \pm 1 \cdot 8 \mathrm{mmol} / 1$. Similarly the deviation of glycaemia from normal levels of blood glucose ( $M$ value) fell in each case. On standard injection therapy the $M$ value was calculated at 54,40 , and 27 respectively. After CSII the $M$ value was 14,34 , and 9 respectively.

There have been no difficulties with the attachment of the machine by day or night. For prolonged exercise the machine is detached. Attendance at school has been unaffected. Flexibility in the daily dietary routine has been the major benefit for all three subjects, together with improvement in general health.

CSII systems 'pumps' appear to be an acceptable therapy for selected children and give near-physiological control of blood glucose.

Social and emotional factors acting in a clinical trial. A L Kinmonth, J D Baum, M Lindsay (Oxford).

The social and emotional factors operating during clinical trials are ethically important and may also affect the results obtained. In a demanding study of the effect of diet on diabetic control the problems discussed by 11 families with the research doctor were documented at weekly intervals for 3 months.

Participating children were aged 11-17 years (mean 14) with variable diabetic control $\left(\mathrm{HbA}_{\mathbf{1}}\right.$ 9.1-16\%; normal reference $7 \cdot 8 \%$ ). Selection was based on: (1) Age $>10$ years; (2) 'Informed' consent; (3) Co-operation with diabetic care; (4) Family stability.

Despite attempts to apply these criteria, it subsequently emerged that one father had doubts about his daughter's participation; one family was suffering from severe marital discord; a girl (17 years) and a boy (10 years) were unexpectedly distressed by the venepunctures required, and another girl (13 years) was persistently falsifying her urine results. However all families wished to complete the trial and only 2 did not, 1 due to recurrent hypoglycaemia and 1 to persistent hyperglycaemia.

The psychosocial problems encountered during the trial were unpredictable and could not be eliminated by selection. Documenting these problems allowed emotional support to be given where necessary, and provided for a fuller and more reliable interpretation of the trial results than would have been possible from the numerical data alone.

The XYY child. S G Ratcliffe, J Nshaho, I Tierney (Edinburgh).

The preliminary results of a longitudinal study of 18 boys with the 47,XYY sex chromosome constitution will be presented. The boys were identified in a newborn cytogenetic survey carried out between 1967 and 1979 in Edinburgh, and are compared with 110 controls from the same newborn population who were matched closely for social class distribution. Anthropometric studies were carried out with the guidance of Professor $\mathbf{J}$ M Tanner, and assessments of speech, intelligence, and behaviour were undertaken by a psychologist who did not know the karyotype, normal or otherwise. Although of average size at birth, by age 5 years all children were above the 50t'in centile for height and 9 of the 18 boys were at or above the 90th centile. Height velocity increased significantly at age 1.5 years.

Differences in behaviour were noted as early as age 3 years with excessive temper tantrums. Speech development was delayed in half the children. Most boys had IQ scores below the mean for the social class-matched controls and lower than their siblings. Fine motor co-ordination and balance were impaired and learning problems were present in $45 \%$. Psychiatric referral was necessary in 6 boys, and was followed by improvement in all cases.

Vitamin $\mathbf{E}$ and neurological function. D P R Muller, J K Lloyd, O H Wolff (London).

Progressive crippling retinopathy and neuropathy are features of abetalipoproteinaemia, and similar spinocerebellar abnormalities may occur in chronic liver disease. Serum vitamin E is virtually undetectable in both conditions and vitamin $\mathrm{E}$ therapy has improved neurological function in liver disease. We report results of treatment in 8 patients with abetalipoproteinaemia followed for 9-20 years and 
recently assessed at ages 10-25 years. None had abnormal retinal function and only the 3 eldest have any neurological abnormality. The eldest ( 25 years) had a pigmentary retinopathy, abnormal retinal function, marked ataxia, and delayed motor nerve conduction velocities at 10 years when vitamin $E$ was started. He now has normal retinal function, less ataxia, and normal motor nerve conduction. The second patient ( 23 years) had absent tendon reflexes at diagnosis ( $1 \frac{1}{2}$ years) and a mild pigmentary retinopathy at 5 years. Since vitamin $E$ treatment at 8 years, retinal appearances have remained unchanged and she has only minimal abnormalities in nerve conduction. The third patient (18 years) was areflexic at diagnosis ( $1 \frac{1}{2}$ years), received vitamin $\mathrm{E}$ from age 3 years, and at 11 years has reduced vibration sense in all limbs but conduction velocities have remained normal.

We conclude that vitamin $\mathrm{E}$ therapy has influenced the natural history of abetalipoproteinaemia. This vitamin appears essential for normal neurological and retinal functioning.

Diagnosis and incidence of cerebral atrophy in the neonate by real-time ultrasound. $M$ I Levene, V Dubowitz, J S Wigglesworth (London).

Perinatal cerebral injury in the newborn infant may be due to intraventricular haemorrhage (IVH), hypoxia, ischaemia, or a combination of these factors. Up to the present, handicap has been correlated with the extent of IVH, as it has not been possible to diagnose damage due to other factors. Using real-time ultrasound we have been able to identify consistent abnormalities which we consider diagnostic of cerebral atrophy. Ischaemia and hypoxia predisposing to atrophy often results in patchy cerebral damage with resultant irregularities in the lateral ventricles. In addition cystic degeneration characteristically seen in periventricular leucomalacia can be recognised. Using a $7 \mathrm{MHz}$ transducer lesions as small as $2 \mathrm{~mm}$ diameter can be detected. A four point grading system has been devised to record the severity of the cerebral atrophy: grade Iirregularities of the lateral ventricle in only one hemisphere; grade II-bilateral irregular dilatation; grade III-cystic degeneration in the cerebral parenchyma; grade IV-severe contraction of the brain with a wide interhemispheric fissure and prominent Sylvian fissures.

During a 1-year period 139 unselected infants of varying gestational ages were repeatedly scanned, and the presence of IVH or cerebral atrophy recorded. Of the 139 infants, $47(34 \%)$ had IVH alone, $27(19 \%)$ had atrophy alone, and $10(7 \%)$ had both IVH and cerebral atrophy. Only 3 infants had evidence of atrophy at birth. In general cerebral atrophy was most common in the more mature infants, whereas IVH was seen most often in the least mature infants. Infants with both IVH and cerebral atrophy were equally distributed through all gestational age groups.

Changes in ultrasound appearance of the neonatal brain with increasing gestation. R W I Cooke, M E I Morgan (Liverpool).

Between 24 weeks' gestation and term, the brain of the human neonate increases considerably in size. The volume change is accompanied by alterations in the prominence, relative size, and complexity of individual intracerebral structures.

The changes in each area of brain with increasing gestation can be visualised using real-time ultrasound examination through the anterior fontanelle of the infant. A lack of understanding of these changes may cause errors in interpretation of appearances; for example, in the extremely preterm infant the cortex is featureless, and the hemisphere substance sonolucent. The choroid plexuses and cerebellum therefore appear very obvious. The ventricular system is fairly large, and the brain does not completely fill the skull cavity. With increasing gestational age, surface convolutions appear, the ventricular spaces become slitlike, and the cerebral substance more sono reflectant.

Cytomegalovirus infection in pregnancy. CS Peckham, K S Chin, J A Davies (London).

Cytomegalovirus (CMV) is the most common congenital infection in man and an important cause of handicap. In September 1979 a prospective study was set up to provide further information on maternal factors associated with CMV infection and to determine the incidence and significance of congenital infection in a British population. This information is urgently required before decisions can be reached on the need for prevention by vaccination. To date, 10000 women from three maternity units in London have been screened for CMV antibodies at their first antenatal attendance. Overall half were found to be seropositive but rates differed from $43 \%$ to $60 \%$ in the three hospitals which each serves a different population. A higher proportion of Asian women were found to have CMV antibodies than other women. Throat swabs have been taken from nearly 10000 newborns and 28 infants with congenital infection have been identified, an incidence of 3 per 1000 births. Four of these 
babies were born after reactivation of maternal infection. All infected babies and 56 closely matched controls are being followed up at regular intervals throughout childhood. In half the infected babies there has been some complication at birth or subsequently-hepatosplenomegaly, pneumonitis, low birthweight for gestational age, recurrent rashes, microcephaly, or sensorineural deafness. Two infants are severely handicapped. It is too early to draw any conclusions from the follow-up examinations since most of the children are still under age 2 years. Further follow-up of infected babies and controls must be continued for at least 5 years so that all defects that may be attributable to intrauterine infection can be identified.

Controlled trials of dry surfactant in preterm infants. A R Wilkinson, J A Jeffery, P A Jenkins (Oxford).

An artificial mixture of dipalmitoylphosphatidylcholine and phosphatidylglycerol $(7: 3)$ prepared as a dry powder (S) was used in two controlled trials in babies born at less than 32 weeks' gestation. All babies in trial 1 were resuscitated by endotracheal intubation and half had $\mathbf{S}$ insufflated into the lungs. Trial 2 consisted of babies with established hyaline membrane disease (HMD) and half were given S. In each trial the control and treated groups were matched for sex. The lecithin/sphinogomyelin ratio (L/S) and phosphatidylglycerol were measured in pharyngeal aspirate in all babies. Eight in trial 1 (4 given S, 4 controls) had mature $\mathrm{L} / \mathrm{S}$ and did not develop HMD. The remaining babies in trial 1 (24) and in trial 2 (24) had similar antenatal and perinatal factors. The $L / S$ was raised in all babies after $S$ but this effect was not maintained. The effect of $\mathbf{S}$ was assessed by studying the change in arterial/alveolar oxygen tension ratio and in trial 2 oesophageal pressure was measured before and after $\mathbf{S}$. There was no difference in the duration of assisted ventilation nor was there a decrease in the complications of HMD between babies given $S$ and the controls in either trial. No immediate or long-term benefits of insufflating $S$ were detected in the babies who developed HMD.

These studies suggest that although $\mathbf{S}$ was deposited in the major airways an intact surfactant monolayer was not maintained.
Birthweight-specific prevalence of cerebral palsy in South East Thames Regional Health Authority 1973 to 1976 births. E Alberman, M Elliott (London).

A register has been assembled of ascertained cerebral palsy in residents in the S E Thames RHA born since 1970. This was done with the help of all paediatricians in the region, and by searches through handicap and death registers. Data collected include the type and severity of each case and, if known, its cause.

A preliminary analysis was presented of birthweight specific prevalence in 1973 to 1976 births of all cases, and those described as diplegic or hemiplegic (Table). These results were compared with rates from earlier years and with data from Sweden and Western Australia; their validity, interpretation, and use were discussed briefly.

The main aim of the presentation was to demonstrate the feasibility of setting up such a register and to demonstrate how it might become an important measure of evaluating perinatal care.

Results of treatment of mucopolysaccharidosis by bone marrow transplantation. $\mathrm{K}$ Hugh-Jones, $\mathrm{P}$ Benson, A D Patrick (London).

All children have been fully documented clinically, radiologically, and biochemically. Three with mucopolysaccharidosis (MPS) type $(1 \mathrm{H})$, of which one has already been reported, have been treated with a bone marrow transplant (BMT) from 18 months to 4 months ago, with a mean duration of $9 \frac{1}{2}$ months; and at a mean age at the time of grafting of 1 year 7 months. The two cases of MPS III B were twins aged 2 years 2 months at the time of grafting which was 2 months ago.

Because none of them had a compatible sibling or unrelated donor all had to have one haplo-type match family donor. Hence all had to survive the rigors of a mismatched transplant with inevitable graft versus host disease (GVHD), and treatment for residual chronic GVHD may be interfering with growth.

Engraftment was proved either by chromosomal studies if appropriate, or by enzyme levels in the leucocytes reaching donor levels which occurred about the 5th week.

Table Cerebral palsy rates per 1000 by birthweight 1973-76 births (provisional results)

\begin{tabular}{|c|c|c|c|c|c|c|c|c|}
\hline & All & $\gtrless 1000^{*}$ & $-1500^{*}$ & $-2000^{*}$ & $-2500^{*}$ & $-2000^{* *}$ & $-2500^{* *}$ & $>3500^{* *}$ \\
\hline $\begin{array}{l}\text { All cases } \\
\text { Diplegics } \\
\text { Hemiplegics }\end{array}$ & $\begin{array}{l}1 \cdot 8 \\
0 \cdot 3 \\
0.4\end{array}$ & $\begin{array}{r}54 \cdot 8 \\
33 \cdot 3 \\
0\end{array}$ & $\begin{array}{r}49 \cdot 1 \\
17 \cdot 8 \\
7 \cdot 1\end{array}$ & $\begin{array}{r}22 \cdot 6 \\
5 \cdot 9 \\
3 \cdot 5\end{array}$ & $\begin{array}{l}5 \cdot 0 \\
0 \cdot 9 \\
0 \cdot 8\end{array}$ & $\begin{array}{l}1 \cdot 9 \\
0 \cdot 3 \\
0 \cdot 3\end{array}$ & $\begin{array}{l}1 \cdot 1 \\
0.2 \\
0.2\end{array}$ & $\begin{array}{l}1 \cdot 2 \\
0 \cdot 1 \\
0 \cdot 3\end{array}$ \\
\hline
\end{tabular}

* Per 1000 neonatal survivors, ** Per 1000 livebirths. 
Other diagnostic parameters-such as urinary creatine glycosaminoglycan ratios-have reverted to near normal levels by 3 months.

Clinically the hepatosplenomegaly had practically disappeared by the 3rd month, corneal clouding was obviously resolving by the 6th month, thereafter the bones can be seen to be slowly remoulding.

Serial CT brain scans have shown a reduction in attenuation. The cases have not been followed up for long enough to make any meaningful comments about developmental progress.

Late deaths in childhood cancer. J E Kingston, G J Draper (Oxford).

One of the principal objectives of long-term followup study set up by the Childhood Cancer Research Group has been to determine the cause and rates of 'late' deaths occurring in children surviving for at least 5 years after diagnosis of a malignant tumour.

We have studied about 4700 children diagnosed before 1971 and among this group there were about 600 deaths which occurred more than 5 years after diagnosis. In the majority of cases information about the cause of death was obtained from hospital and general practice records.

We found that late death rates in children with certain tumour types, notably those with CNS tumours and Hodgkin's disease, remained high for up to 15 years after diagnosis. The main cause of death in these patients was recurrent disease. This was in contrast to patients with retinoblastoma for whom late death rates were fairly low and in whom the most common cause of late death was the development of a second primary tumour. Second malignancies and deaths due to complications of treatment have been seen in nearly all tumour types.

In conclusion, about 1 in 8 of this group of 5-year survivors of childhood cancer have died during the subsequent 10-year period. For certain tumour types 5-year survival cannot be equated with 'cure'.

Social class as a prognostic variable in lymphoblastic leukaemia. W R McWhirter, H Smith (Australia).

A series of 80 children under age 15 years with acute lymphoblastic leukaemia (ALL) diagnosed between 1975 and 1980 were studied. Only those children for whom curative chemotherapy, including CNS prophylaxis, was attempted were included. On the basis of father's occupation each was allocated to one of seven social classes. The cases were divided into two groups: group 1 consists of 55 children in social class 1-5, and group 2, 25 children in classes 6-7. Life table analysis was used to examine their survival experience. The 5-year survival rate for group 1 was $63 \%$ and for group $2,11 \%$. The median survival times were 74 and 25 months respectively. The difference between the two groups is significant $(P=0.01)$.

Possible reasons for the difference in survival include a biological difference in the types of leukaemia in upper and lower social classes, a difference in compliance with therapy, or the influence of factors such as nutrition. This study identifies an important subgroup of children with ALL who have a poor prognosis, and further studies are in progress to try to identify the factors involved, as there are clearly important implications for treatment. They differ from most other prognostic factors in being potentially amenable to treatment.

Lethal syndrome of delayed umbilical cord separation, defective neutrophil mobility, and absent natural killer cell activity. E G Davies, D Isaacs, $R$ J Levinsky (London and Harrow).

The association of delayed separation of the umbilical cord with widespread infections and defective neutrophil mobility was first described in 5 infants in 1979. All those children have subsequently died from infective complications. We have since studied two further cases. Both had recurrent severe bacterial, viral, and candidal infections. Hepatosplenomegaly was also a prominent feature. In addition to severely impaired neutrophil mobility we found an absence of natural killer cell (NK) activity. Humoral immunity, neutrophil killing and T-cell numbers, subsets, and mitogen responsiveness were all normal.

In the first patient, incubation of peripheral blood mononuclear cells with interferon produced an increase in NK activity while in the second case a complete inability to produce immune ( 8 ) interferon was demonstrated. Though the children were reasonably well when investigated both have since died from septicaemia.

We believe these children had defective immune interferon production, resulting in deficiency of NK activity. This may well have been the more important defect in determining the fatal outcome, since other children with equally impaired neutrophil mobility but normal NK activity do not generally have such a poor prognosis.

Defective suppressor cell activity in atopic eczema. R J Levinsky, M Butler (London).

The production of IgE is under T-cell control and an imbalance of helper and suppressor $\mathrm{T}$ cells has been suggested as the mechanism underlying severe atopy.

We have studied 16 children suffering from severe atopic eczema for imbalances in the numbers of 
helper and suppressor T-cells using monoclonal antisera specific for these populations. In addition functional activity of these cells was measured by Conconavalin A (Con A) activation and suppression of pokeweed mitogen (PWM) induced immunoglobulin production by plasma cells and Con A proliferation of T-cells. Compared with children and adult controls (median 1.8) eczema patients had significantly higher helper/suppressor ratios (median $2.65 \mathrm{P}<0.002$ ) indicating a lack of suppressor cells. Using the functional assays a similar lack of suppression was shown (Con. A/PWM $\mathrm{P}<0.02$; Con.A/Con.A $\mathrm{P}<0.05)$. There was a significant inverse correlation between helper/suppressor ratio and suppressor activity $(P<0.01)$.

These results indicate that a defect in T-cell regulation does exist in atopic eczema and if it is of primary pathogenic importance, immunotherapy to restore the balance may prove useful.

Use of renal vein renin measurements in the investigation and management of childhood hypertension. L A Roomi, A V Murphy, C S Nelson, R D Paton, M A Ziervogel (Glasgow and Derby).

Forty-two patients aged one to 17 years with hypertension were investigated by renal vein renin measurements. Renin levels were measured either as plasma renin concentration or as plasma renin activity. In 49 procedures no serious complications occurred and technical failure occurred only twice.

Analysis of our results showed that in 18 patients there was evidence of asymmetrical renin release. Surgery was performed in 15 of this group. Twelve as judged by normal blood pressure without therapy obtained a complete cure on 3 months to 6 year follow-up (average 18 months). Ten of these had unilateral and two bilateral renal disease. In the remaining 3 there was improved blood pressure control.

We conclude renal vein renin studies have an established place in the investigation and management of childhood hypertension. Our own experience underlines the value of investigation of patients with both unilateral and bilateral renal disease. We have shown cure or improved control of hypertension in a significant number of the patients investigated.

Primary cleft lip repair in the newborn and early cleft palate repair at 16 weeks. S Desai, B Christie, M TooChung (Stoke Mandeville).

Cleft lip repair is usually carried out at age 12 weeks and cleft palate after 4 months of age. For the last 15 years we have been repairing cleft lip deformities within the first $\mathbf{4 8}$ hours of life. The babies have been followed up in our combined Cleft Lip and Palate Clinic and the palate has been repaired at 3-4 months. Our cases (175 up to August 1981) have been compared with those closed at a later age in other units. Examination was made of the complete deciduous dentition from models of the dental arches and teeth in occlusion. From this measurement a scientific base was provided for comparison. Cephalometric analysis from standardised lateral skull $x$-ray films was made and results in the two groups compared. The babies were examined by impedance audiometry and it was shown that those undergoing operative repair in the first $\mathbf{4 8}$ hours of life had normal tympanograms. Middle ear malfunction commonly occurs after 4 months of age and as the frequency of middle ear malfunction is reduced once the palate is repaired, we recommend that the operation be performed before age 4 months. Early repair of the hare lip undoubtedly leads to an improved mother-baby relationship, and the effect on the mother of repairing the grotesque lip deformities at birth has been remarkable. It is not known if this work is performed in units other than our own.

\section{PAEDIATRIC UROLOGY SESSION}

Prospective controlled trial of operative versus nonoperative management of severe vesicoureteric reflux -a 2-year follow-up of 96 children. R H R White, R Astley, R C Clark, J J Corkery, P Gornall, K J Shah, C M Taylor, M H Winterborn (Birmingham).

Since 1975 at Birmingham Children's Hospital children with urinary tract infection (UTI) found to have severe primary vesicoureteric reflux (VUR) have been randomly allocated to operative or nonoperative management in 3 age groups: $0-1$ years, 1-6 years, and 6-15 years. Continuous chemoprophylaxis has been given to both operative and nonoperative groups throughout the first 2 years. Radiological and renal function assessment has been carried out at entry, at 2 years, and 5 years, and patients have been seen regularly between assessments for urine analysis and blood pressure recording. Of 109 children who have reached their 2-year follow-up, 13 have been withdrawn for failure to comply with protocol or because of inadequate data. Severe VUR was unilateral in 57 and bilateral in 39 instances providing 135 'renal units' for analysis in 96 children.

Renal function, renal scarring (new scars, extension of existing scars), renal growth and incidence of breakthrough UTI were similar in the operative and non-operative groups. Only 1 child was hypertensive at entry and no child developed hypertension by 2 years. At the 2-year follow-up stage ureteric 
reimplantation appears to offer no benefit to kidneys in addition to that provided by chemoprophylaxis alone. In most patients managed non-operatively VUR persisted and in many remained at severe degree. Surgical reimplantation was $97 \%$ successful in abolishing VUR and without serious complications.

Renal dysplasia in the kidney with a duplex pelvicalyceal system: clinical and pathological features. $P$ C Gartell, J D Atwell, A MacIver (Wessex and Southampton).

Renal dysplasia can be classified into three main groups; those with an atretic ureter, those with urethral obstruction, and those with a patent but abnormal ureter. A duplex pelvicalyceal collecting system is often associated with the last group.

We have seen 34 patients ( 36 renal units) who have had a heminephrectomy. The degree of obstruction and dysplasia has been assessed in 26 patients with ectopic ureteroceles (7), ectopic ureters (11), and reflux (8). Eight other patients were also studied.

Dysplasia was classified as either focal or diffuse and ranged in severity from mild $(+)$, to moderate $(++)$ and severe $(+++)$. Dysplasia was found in all patients with an ectopic ureter, in $85 \%$ of those with ectopic ureteroceles, and in $67 \%$ with reflux to the lower pole of the kidney. In patients with ectopic ureteroceles the dysplasia was usually severe $(6 / 7)$ whereas in patients with ectopic ureters the dysplasia was often severe $(6 / 11)$ but many cases showed moderate $(3 / 11)$ or mild $(2 / 11)$ changes. In 9 renal units with reflux the dysplasia was rarely severe (2/9) and absent in 3 patients. Thus there appears to be a direct correlation between the severity of renal dysplasia and the degree of ureteric obstruction.

Tumours causing lower urinary tract obstruction. D G Young (Glasgow).

Tumours causing lower urinary tract obstruction are uncommon in infancy and childhood. During the last 30 years at the Royal Hospital for Sick Children, Glasgow, 23 patients have been admitted in whom marked lower urinary obstruction was caused by a tumour.

The tumours causing the obstruction were: teratoma 10 , sarcoma 8 , neuroblastoma/ganglioneuroma 3, lymphoma 2 , and hamartoma 1 .

The age at presentation varied from birth to 10 years and 14 of the patients were boys.
Cysto-urethroscopy in infancy and childhood: its use and limitations. H B Eckstein (London).

Urological endoscopy is not new and has, in one way or another, even in childhood been available for some 50 years. However, previous instruments were dependent on batteries, long electric cables, and extremely fragile light bulbs, so that endoscopy was an unpredictable and unreliable exercise. The development of modern fibre optic endoscopes in the last decade, especially by Storz, Wolff, and ACMI, has revolutionised this investigation and has produced reliable instruments with cold light illumination which enables photographic and indeed video tape pictures to be taken.

The author's approach has always been rather conservative and endoscopy has in his hands only been carried out if there was a positive indication for the procedure. Two hundred consecutive endoscopies performed during a period of 4 years at Queen Mary's Hospital for Children have been reviewed. It is of note that in such selected patients $(200$ children) positive endoscopic findings relating to the final diagnosis were present in $55 \%$ and if children with either urinary tract infection or enuresis were considered as a special group the incidence of abnormalities was $35 \%$.

It was therefore felt that a control study should be performed and for a few months thereafter endoscopy was added to the primary range of investigation in all urological patients. If all patients underwent endoscopy the detection of abnormalities was reduced to $19 \%$ in the total group and to $12 \%$ in those children who had automatic routine endoscopy for enuresis or urinary tract infection only.

The conclusions that can be drawn from this study suggest that cysto-urethroscopy as an investigatory procedure should be reserved for children in whom there is a positive indication for endoscopy which in childhood always requires a general anaesthesia and therefore admission to hospitals if even for a short period of time.

Urethral valves-presentation in the neonatal period. S J Cohen (Manchester).

The presentation of neonatal cases of urethral valves can be a problem in both diagnosis and management. The patient very rarely presents with the recognised story of poor urinary stream and dribbling but is much more likely to present with failure to thrive, vomiting, or convulsions.

The radiographic diagnosis presents no problem provided a good view of the posterior urethra on micturating cystography is obtained. One should 
always use the suprapubic route both for this investigation and for the emergency treatment, and never pass a urethral catheter.

During the last two decades the prognosis has changed greatly. Previously very few cases would survive the first year of life, but now the excellent care which the paediatric nephrologists give regarding feeding and electrolyte balance enables these children to survive albeit with damage to the upper urinary tract.

The surgical treatment is initially to diathermy the valves, but even this may be insufficient to allow free drainage and one may have to contemplate doing a urinary diversion.

The latest advance is that these abnormalities are being detected by ultrasound screening of the pregnant mother. This poses the problem of whether one can in any way treat these valves in utero or as an alternative, perhaps terminate the pregnancy a little sooner if there is good evidence of increasing hydronephrosis. At present these are just options open to us but may well be of value in the future management.

Spectrum of vesico-ureteric reflux: a study of 2000 micturating cystourethrograms. B O'Donnell (Dublin).

\section{POSTER PRESENTATIONS}

Growth and hormonal status of children treated for medulloblastoma. I H Brown, J Bullimore, O B Eden, T J Lee, D C L Savage.

Daily output of deoxyribonucleic acid (DNA) and sputum weight in cystic fibrosis patients. F Carswell, D W Robinson, C C L Ward, M R Waterfield.

Feeding very low birthweight babies: practical problems. M A Clarke, D P Davies, N Whittacker.

Neonatal ventilator computer simulation. G Clayden.

Development of a neonatal transport trolley. D A Ducker, J S Smith.

Oxygen consumption during skin-to-skin contact between mother and baby immediately after birth. E P G Ester, J Crum, R Dinwiddie, M J E Eliasar, E Freud, D Harvey, I Kovar.

\section{Aetiology of aplastic anaemia. D I K Evans.}

Birthweights and head circumferences of 20750 neonates of gestational age 23 to 42 weeks. $J$ A Eyre, C Redman, J P M Tizard, A R Wilkinson.
Budesonide in childhood asthma. $\mathrm{H}$ Field, $\mathrm{P}$ Jenkinson, M Frame, S Partridge, J Warner.

Autosomal recessive muscular dystrophy in childhood. D Gardner-Medwin, H Johnston.

Clinic for communication disorders. D M B Hall, D Klein.

Ultrasound imaging in the diagnosis of muscle disease: a new and non-invasive approach. $J Z$ Heckmatt, V Dubowitz, S Leeman.

Needle muscle biopsy: a practical technique for muscle disorders in children. $\mathrm{J} Z$ Z Heckmatt, V Dubowitz, C Hutson, A Moosa.

Childhood prognosis for congenital hypothyroidism. J A Hulse.

Adrenal steroid excretion in childhood and the mechanism of adrenarche. C J H Kelnar, C G D Brook.

Analysis of 53 episodes of hepatic crisis in 48 West African children with sickle cell disease. V F Larcher, W N Kaine, A P Mowat.

Growth in children with diabetes. $\mathrm{T} \mathrm{J}$ Lee, D C L Savage, J Wadsworth.

Progressive spastic paraplegia due to echo virus encephalomyelitis in a child with $\mathrm{X}$-linked hypogammaglobulinaemia. $\mathbf{S}$ Lingam, $J$ Egger, $M$ Erdohazi, J Wilson.

Glucose galactose malabsorption in an Asian family. P I MacFarlane, A Robinson.

Intestinal lactase, sucrase, and alkaline phosphatase in 477 subjects with normal mucosa. B McNicholl, B Egan-Mitchell, P F Fottrell, J G O'Grady, R Keane, C F McCarthy, J Shiels, F M Stevens.

Epidemiology of childhood brain tumours. W R McWhirter, J Bell, A Tannenberg.

Basophil histamine release in response to milk, and its relevance to food allergic diseases. $\mathrm{J} K$ Mitchell, $H$ Brown, $R$ R A Coombs, $P$ Hutchins, $P$ McLaughlin, J A Walker-Smith.

Complications of long-term prostaglandin $E_{2}$ therapy in infants with complex heart disease. $P$ Morrell, H H Bain, S Hunter, G R Sutherland. 
Who checks the inner city toddler? A Nicoll.

Agenesis of the corpus callosum. B L Priestley, J Lorber.

Umbilical cord brain specific creatine kinase. C W E Redman, E F Foster, R D G Milner, R J Thompson.

Alveolar-arterial nitrogen gradients in preterm infants requiring ventilatory support. $\mathrm{G} J$ Reynolds.

Rapid stool viral diagnosis by electron microscopy. S Rice, J A Walker-Smith.

Plasma creatinine in the neonatal period-a normal range. $\mathbf{P}$ T Rudd, D T Hodes, E A Hughes, M M Placzek.

Congenital hypertrophic pyloric stenosis in monozygotic twins. N Shabde, B Thalayasingam.

Nocturnal hypoglycaemia and insulin treatment in young diabetics on holiday. P G F Swift, $H$ Barker, P Clarke, J Nelki, K Steer, S Strang.

Prophylactic phenobarbitone and hyperbilirubinaemia in very low birthweight infants. $P J$ Todd.

Peripheral white cell counts as a prognostic indicator in bacterial meningitis in children over age one month. E Wing.

GROUP SESSIONS

Joint Group Session of the British Paediatric Neurology Association and the Community Paediatric Group

Analysis of psychosomatic problems in children. R J Robinson.

Hemiplegic cerebral palsy. J K Bown.

Possible neurological dysfunction and early school status: a total population study. C M Drillien.

Clinic for communication disorders. D M B Hall, D Klein.

Prognosis for abused children: a 7 year follow-up study. O J Hensey, L Rosenbloom, J K Williams.

Clinical review of spino-cerebellar degenerations in childhood. R S Ackroyd, J A Finnegan, S H Green.
European concerted action project on congenital malformations and multiple births (EUROCAT). J R Owens, F Harris, E McAllister, L West.

BPA Classification of Diseases-no thanks, I'd rather use my own! D H Mellor.

British Paediatric Nutrition, Metabolism, and Pharmacology Group

Lead levels and abnormal births. F W Alexander, T Talbot.

Effect of insulin in parenteral nutrition of the sick preterm infant. A Harvie, M Giles, S K Jorge, F Sim.

Postoperative intravenous feeding regimen in neonates-should the extent of surgical trauma be considered? M J Greenall, M H Gough, R Yardley.

Vitamin D-resistant rickets associated with rifampicin therapy. M O Savage, C Eggerding, V M Novelli, W C Marshall.

Can an amino-acid molar ratio provide information about hepatocellular function in infants? $\mathbf{J} F \mathbf{T}$ Glasgow, R Moore.

Body composition changes in obese adolescents on a protein sparing modified fast. E H Archibald, J Harrison, P B Pencharz.

Effect of fever on drug metabolism in children. J S Forsyth, T A Moreland, G W Rylance.

Factors influencing somatic size at six weeks in breast-fed babies. L S Taitz, Z Lukmanji.

Magnesium transdefect-a new inborn error. L Sinclair.

Diagnostic investigation and management of an infant with dihydropteridine reductase deficiency detected on routine screening for tetrahydrobiopterin $\left(\mathrm{BH}_{4}\right)$ deficiency among infants with phenylketonuria. I Smith, F Besag, O H Wolff.

Hyperammonaemia associated with hyperlysinaemia: a disorder of urea cycle responding to supplementation with L-arginine. I B Sardharwalla, A Holmes, E Wraith.

Improving the energy value of donor breast milk. R J Stocks, E Broderick, L P Carroll, D P Davies, M Parker. 


\section{British Society for Paediatric Endocrinology}

Neonatal screening for hypothyroidism in East Anglia. N D Barnes, A F Heeley.

Specific androgen binding in genital and nongenital skin fibroblasts in androgen-insensitive patients and controls. E M C Duke, M B Hodgins.

Predictability of blood glucose patterns measured at home and their improvement. A L Kinmonth, J D Baum, G Werther.

Effects of fibre, beans, and exercise on diabetic control. J H Baumer, J Drakeford, D C L Savage, J Wadsworth.

Age and height increment of the pubertal growth spurt in diabetic children. S L Stewart Brown, D C L Savage, M Waterfield.

Sleep studies in pituitary gigantism. N C Fraser, R A Minns.

Influence of breast feeding on age at diagnosis of salt-losing congenital adrenal hyperplasia. J A Curtis, J D Bailey.

Joint Group Session of the British Paediatric Perinatal Group and British Paediatric Respiratory Group

Current status of surfactant. C Morley.

Deep barbiturate coma in the management of very severe birth asphyxia. J A Eyre, J W Keeling, J P M Tizard, A R Wilkinson.

Pulmonary function 7-11 years after preterm birth C Noble-Jamieson, M Silverman.

Effect of gravity on pulmonary gas exchange in infants. D P Heaf, I Gordon, P J Helms, M G Hulse.

Feto-fetal transfusion syndrome. P Galea, A Ford, K M Goel, J C MacLaurin, J Scott.

Parent meetings in neonatal intensive care unitsa way of increasing parental support. J Dammers, V Halpin.

Joint Group Session of the British Paediatric Oncology and Haematology Group and the British Paediatric Immunology and Infectious Diseases Group

Prenatal diagnosis for severe combined immunodeficiency. R J Levinsky, P C L Beverley, D C Linch, C H Rodeck.
Neutrophil function in the immotile cilia syndrome. C W B Corkey, W D Biggar, J O Minta, J A P Turner.

House dust mite allergen intake in young infants. F Carswell, J Clark, T A E Platts-Mills.

Prospective study of infection and atopy in infants with yeast opsonisation deficiency. V F Richardson, V F Larcher, J F Price.

Impaired serum stimulatory activity for polymorphonuclear leucocyte movements in children with sickle cell disease. V F Larcher, I A Rajkovic, R Williams, R J Wyke, A G M Yousif-Kadaru.

Neurological complications of childhood acute lymphoblastic leukaemia with special reference to disseminated leucoencephalopathy. A Bligh, B Brownell, J F Murphy, E N Thompson.

Leucocyte subsets in neonates. $\mathbf{R}$ M Thomas, D C Linch.

Small bowel function in children with malignancy. A D J Pearson, A W Craft, E J Eastham, M F Laker.

Subcutaneous desferrioxamine in patients with thalassaemia major receiving blood transfusions: appraisal after 4 years. D M Flynn, A V Hoffbrand. D Politis.

Unpredictable mercaptopurine bioavailability in childhood leukaemia. S M Herber, L Lennard, J S Lilleyman, J L Maddocks.

Joint Group Session of the British Paediatric Gastroenterology Group, the British Paediatric Nutrition, Metabolism, and Pharmacology Group, and the British Paediatric Tropical Child Health Group

Inter-relationship between diarrhoea and malnutrition. M G M Rowland.

Nutrition and infection-a British view. E M E Poskitt.

Role of mucosal adhesion of $E$. coli in human diarrhoea. D C A Candy, S Knutton, D R Lloyd, A S McNeish.

Morphological studies of bacterial cytotoxicity in infants with diarrhoea and malnutrition. A D Phillips. 
Trace metals in diarrhoea and malnutrition. $\mathbf{P} \mathbf{J}$ Aggett.

Prospective study of sugar intolerance complicating acute gastroenteritis. J Q Trounce, J A Walker-Smith.

\section{BPA General Session}

Weighing babies in health clinics: an appraisal of a well established practice. D P Davies.

Pharmacological prevention of neonatal periventricular haemorrhage. M E I Morgan, R W I Cooke.

Cerebral blood flow in the newborn baby studied by electrical impedance plethysmography. A M Weindling, K Costeloe, N Murdoch, P Rolfe, D P L Smyth, L Tarassenko, J P M Tizard.
Auditory brainstem responses: potential value in neurologically abnormal neonates. C L Fawer, L M S Dubowitz, V Dubowitz, M I Levene.

Minor epileptic status: clinical and neurophysiological features and treatment. S Lingam, A Battaglia, E M Brett, J Crum, J Wilson.

Use or abuse of phototherapy for physiological jaundice at term. H Lewis, R H A Campbell, G Hambleton.

Does health education prevent childhood accidents? P E Minchom, M Bowley, R Newcombe, J R Sibert.

Evaluation of a home based child health record book. A Lakhani, A Avery, G Clayden, A Gordon, N Tait.

British Paediatric Association

Annual meetings

1983 12-16 April York University

1984 10-14 April York University

1985 16-20 April York University

1986 15-19 April York University

1987 7-11 April York University 